\title{
DOSES OF CONTROLLED-RELEASE FERTILIZER FOR PRODUCTION OF RUBBER TREE ROOTSTOCKS
}

\author{
Antonio Nilson Zamunér Filho', Nelson Venturin², Ailton Vitor Pereira ${ }^{3}$, \\ Elainy Botelho Carvalho Pereira ${ }^{4}$, Renato Luis Grisi Macedo ${ }^{5}$
}

(received: February 5, 2010; accepted: December 22, 2011)

\begin{abstract}
This experimental study aimed to evaluate the effects of doses of controlled-release fertilizer (ALL) on the development of rubber tree rootstocks. The fertilizer used was Osmocote ${ }^{\circledR}$, scheduled to be released for 8-9 months and with the following composition: $\mathrm{N}(15 \%), \mathrm{P}_{2} \mathrm{O}_{5}(9 \%), \mathrm{K}_{2} \mathrm{O}(12 \%), \mathrm{Mg}(1 \%), \mathrm{S}(2.3 \%), \mathrm{B}(0.02 \%), \mathrm{Cu}(0.05 \%), \mathrm{Fe}(1 \%), \mathrm{Mn}(0.06 \%), \mathrm{Mo}(0.02 \%)$ and $\mathrm{Zn}(0.05 \%)$. A randomized block design was used, with four treatments and eight replicates of 20 plants per plot. The controlledrelease fertilizer was added to Rendimax Floreira ${ }^{\circledR}$ substrate at doses of 0, 3,6 and $9 \mathrm{~g}$ per liter, and rootstocks were produced in plastic containers with a capacity of two liters of substrate. Three seeds of clone GT 1 were scattered in each container and thinning was performed on day 60, leaving the most vigorous plant only. After the fourth leaf shot from each rootstock, the containers of each treatment were topped, due to compaction, with $300 \mathrm{~mL}$ of the relevant fertilizer and substrate mixture. The rootstocks were evaluated at eight months of age as to height, stem diameter (DC) $5 \mathrm{~cm}$ above root collar, total dry matter, shoot and root dry matter, leaf nutrient levels and percentage of plants suitable for grafting $(\mathrm{DC} \geq 1.0 \mathrm{~cm})$. Results revealed that adequate development and nutrition of rootstocks was achieved by using $6 \mathrm{~g}$ of controlled-release fertilizer per liter of substrate.
\end{abstract}

Key words: Hevea brasiliensis, seedling, fertilization, nutrition.

\section{DOSES DE ADUBO DE LIBERAÇÃO LENTA PARA PRODUÇÃo DE PORTA-ENXERTOS DE SERINGUEIRA}

RESUMO: O experimento foi conduzido com o objetivo de avaliar os efeitos de doses de adubo de liberação lenta (ALL) sobre o desenvolvimento de porta-enxertos de seringueira. O adubo utilizado foi o Osmocote ${ }^{\circledR}$, com liberação prevista para 8-9 meses e a seguinte composição: $\mathrm{N}(15 \%), \mathrm{P}_{2} \mathrm{O}_{5}(9 \%), \mathrm{K}_{2} \mathrm{O}(12 \%), \mathrm{Mg}(1 \%), \mathrm{S}(2,3 \%), \mathrm{B}(0,02 \%), \mathrm{Cu}(0,05 \%), \mathrm{Fe}(1 \%), \mathrm{Mn}(0,06 \%), \mathrm{Mo}$ $(0,02 \%)$ e Zn $(0,05 \%)$. O delineamento experimental foi em blocos ao acaso com quatro tratamentos e oito repetições de 20 plantas

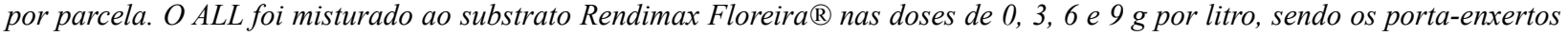
produzidos em recipientes plásticos com capacidade para dois litros de substrato. Foram semeadas três sementes do clone GT 1 por recipiente e feito o desbaste aos 60 dias de idade, deixando apenas a planta mais vigorosa. Após o quarto lançamento foliar dos porta-enxertos, os recipientes de cada tratamento foram completados com $300 \mathrm{~mL}$ das respectivas misturas de ALL e substrato, em razão do acamamento deste. Os porta-enxertos foram avaliados aos oito meses de idade quanto a altura da planta, diâmetro do caule (DC) a $5 \mathrm{~cm}$ do coleto, matéria seca total, da parte aérea e das raízes, teores foliares de nutrientes e porcentagem de plantas aptas à enxertia $(D C \geq 1,0 \mathrm{~cm})$, constatando-se desenvolvimento e nutrição adequados dos porta-enxertos com a dose de 6 $g$ de ALL por litro de substrato.

Palavras-chave: Hevea brasiliensis, muda, adubação, nutrição.

\section{INTRODUCTION}

Hevea brasiliensis (Willd. ex Adr. de Juss.) Müell. Arg., commonly known as rubber tree, is of major economic importance to Brazil and the world alike because its sap-like extract is the primary source of natural rubber. Rubber is used in the manufacture of tires and hundreds of artifacts used in various industry sectors, including health and electronic devices, domestic appliances and footwear, mining and steel industry, entertainment business and other activities (SAMPAIO FILHO et al., 2006).

\footnotetext{
${ }^{1}$ Agronomic Engineer, D.Sc. Candidate in Transportation Engineering - Departamento de Engenharia de Transportes - Escola de Engenharia de São Carlos - Av. do Trabalhador Sãocarlense 400, Pq Arnold Schimidt - 13566-590 - São Carlos, SP - antoniozamuner@hotmail.com ${ }^{2}$ Forest Engineer, Professor D.Sc. in Soil Science - Departamento de Ciências Florestais - Universidade Federal de Lavras/UFLA - Cx. P. 3037 37200-000 - Lavras, MG - venturim@dcf.ufla.br

${ }^{3}$ Agronomic Engineer, Researcher D.Sc. in Agronomy/Plant Science - Embrapa Transferência de Tecnologia - Escritório de Negócios de Goiânia Km 4, BR 153, Saída para Anápolis - Cx. P. 714 - 74001-970 - Goiania, GO - ailtonvpereira@yahoo.com.br

${ }^{4}$ Agronomic Engineer, Researcher D.Sc. in Agronomy/Plant Science - Agência Goiana de Desenvolvimento Rural e Fundiário - Rua Jornalista Geraldo Vale, 331 - Setor Leste Universitário - Cx. P. 331 - 74610-060 - Goiânia, GO - elainy_pereira@yahoo.com.br

${ }^{5}$ Agronomist, Professor D.Sc. in Forest Engineering - Departamento de Ciências Florestais - Universidade Federal de Lavras/UFLA - Cx. P. 3037 37.200-000 - Lavras, MG - rlgrisi@dcf.ufla.br
}

Cerne, Lavras, v. 18, n. 2, p. 239-245, abr./jun. 2012 
The demand for natural rubber has been increasing every year, and Brazil is the world's 5th largest consumer market $(341,580 \mathrm{t})$ against a total output of $109,800 \mathrm{t}$ (GAMEIRO, 2009). According to Cortez (2005) and Sampaio Filho et al. (2006), consumption of natural rubber in Brazil could reach 1 million tons by the year 2030 . In order to become self-sufficient, Brazil will have to expand the existing area of rubber tree crops by about 50 thousand hectares a year (SAMPAIO FILHO et al., 2006), requiring 25 million seedlings per year, which represents a bottleneck limiting crop expansion.

Typically, seedlings are produced in ground conditions using the soil as a substrate and plastic bags as containers, which are then furrow buried in delimited plots, requiring intensive use of labor in barely comfortable or productive working positions. As in this system containers are perforated, seedlings develop mainly on the outer part and thus become poorly rooted and susceptible to loss once grafted and pulled out of the container for field planting. In addition, this system involves a higher risk that weeds and nematodes present in the soil will be disseminated, potentially affecting the overall performance of the rubber tree crop (PEREIRA et al., 2007). To avoid such constraints, these authors proposed an alternative nursery system for production of rubber tree seedlings which is suspended $1 \mathrm{~m}$ above ground and consists of seedling tubes and light, porous commercial substrates composed of tree or coconut bark.

In the traditional method, rubber tree seedlings are fertilized with readily available sources that favor rapid uptake and leaching of nutrients, and which are thus less suitable for hanging seedlings produced in light, porous substrates and subject to daily irrigation.

A promising and increasingly popular alternative among nursery workers is use of controlled-release fertilizers consisting of fertilizer granules coated with an organic resin layer that regulates nutrient release. Water vapor penetrates the granules and dissolves nutrients, which are gradually released into the substrate as a function of current moisture and temperature, with higher temperatures favoring faster release for shorter periods (SCOTTS UK PGB, 2002). These fertilizers purport to meet the nutritional needs of plants while minimizing not only the use of soluble sources but also labor costs, nutrient waste and potential environmental pollution from nutrient leaching (PERIN et al., 1999).

This study aimed to evaluate the effects of different doses of a commercial formulation of controlled-release fertilizer on the development of rubber tree rootstocks.

Cerne, Lavras, v. 18, n. 2, p. 239-245, abr./jun. 2012

\section{MATERIAL AND METHODS}

The experiment was conducted under field conditions in the municipality of Goiania/GO, at the unit Embrapa Technology Transfer - Goiania Business Office. According to Köppen classification, the local climate is Aw type and thus suitable for rubber tree crops according to agroclimatic zoning maps proposed by Camargo et al. (2003).

The experiment used a randomized block design with eight replicates of twenty plants per plot, and treatments consisted of $0,3,6$ and $9 \mathrm{~g}$ doses of controlledrelease fertilizer (ALL) per each liter of substrate prior to filling out containers. The fertilizer used was Osmocote $\AA$, scheduled to be released for 8 to 9 months and composed of: $\mathrm{N}(15 \%), \mathrm{P}_{2} \mathrm{O}_{5}(9 \%), \mathrm{K}_{2} \mathrm{O}(12 \%), \mathrm{Mg}(1 \%), \mathrm{S}(2.3 \%)$, $\mathrm{B}(0.02 \%), \mathrm{Cu}(0.05 \%), \mathrm{Fe}(1 \%), \mathrm{Mn}(0.06 \%)$, Mo $(0.02 \%)$ and $\operatorname{Zn}(0.05 \%)$. Once the fourth leaf of rootstocks matured, the containers of each treatment were topped, due to compaction, with $300 \mathrm{~cm}^{3}$ of the relevant initial fertilizer and substrate mixture.

The substrate used was Rendimax Floreira ${ }^{\circledR}$, a compost of pine bark, peat and vermiculite having the following characteristics: moisture $(47.8 \%)$, wet density $\left(750.3 \mathrm{Kg} / \mathrm{m}^{3}\right)$, dry density $\left(392.2 \mathrm{Kg} / \mathrm{m}^{3}\right)$, water holding capacity $(144.9 \% \mathrm{w} / \mathrm{w}), \mathrm{pH}(5.1)$, electrical conductivity $(1.2 \mathrm{~S} / \mathrm{m})$, total porosity $(80.2 \% \mathrm{v} / \mathrm{v})$, nutrient content: $\mathrm{N}$ $(9 \mathrm{~g} / \mathrm{Kg}), \mathrm{P}(0.9 \mathrm{~g} / \mathrm{Kg}), \mathrm{K}(2.6 \mathrm{~g} / \mathrm{Kg}), \mathrm{Ca}(7.4 \mathrm{~g} / \mathrm{Kg}), \mathrm{Mg}$ (11.1 g/Kg), S (1.7 g/Kg), Fe (8.2 g/Kg), B (15.2 mg/Kg), $\mathrm{Cu}(19.4 \mathrm{mg} / \mathrm{Kg}), \mathrm{Mn}(127.0 \mathrm{mg} / \mathrm{Kg}), \mathrm{Zn}(30.2 \mathrm{mg} / \mathrm{Kg})$, organic carbon $(295.7 \mathrm{~g} / \mathrm{Kg})$ and $\mathrm{C} / \mathrm{N}$ ratio: 32.9 .

For simulation of seedling production in hanging seedling tubes, $15 \times 30 \mathrm{~cm}$ black plastic bags were used, with the bottom perforated and placed in plastic soft drink bottles with a capacity of 2 liters. The bottom part of each bottle was removed and bottles were then hung with the top side down $1 \mathrm{~m}$ high, on the supporting structure made from eucalyptus poles and fence wire, leaving $1.2 \mathrm{~m}$ spacing between double rows, according to Pereira et al. (2007).

Seed scattering consisted of three newly collected seeds of clone GT 1 per container, topped with around $200 \mathrm{~mL}$ of fine vermiculite. On day 60, thinning was performed to leave the most vigorous seedling in each container. Spray irrigation was used to start with, followed by drip irrigation so as to minimize nutrient leaching from the substrate.

Weed control was done manually and confined to the inside of the plastic bags due to use of the substrate. Eggs and larvae of hornworm mandarová (Erinnyis ello L.) 
were removed manually, and beetle vaquinha (Diabrotica speciosa) was controlled by spraying deltamethrin-based insecticide. No disease occurrence was detected in plants throughout the experimental period.

Effects of each treatment on the development of rubber tree rootstocks were evaluated after eight months, based on the following variables: plant height, stem diameter (DC) $5 \mathrm{~cm}$ above root collar, percentage of plants suitable for green grafting $(\mathrm{DC} \geq 1 \mathrm{~cm}$ ) according to set standards for rubber seed and seedling production and commercialization (BRASIL, 2009), total dry matter, shoot dry matter and root dry matter (an average of three specimens per each plot), and nutrient levels. Development-related data were submitted to analysis of variance and polynomial regression whenever significant effects were found.

\section{RESULTS AND DISCUSSION}

Analysis of variance procedures (Table 1) revealed that varying doses of controlled-release fertilizer (ALL) had highly significant effects on rootstock development as to height, stem diameter, total dry matter, shoot dry matter and root dry matter.

The low coefficient values indicate effective experimental control that helps minimize errors. Significant growth responses from rootstocks to traditional chemical fertilization were observed by Coelho (1991), Marques (1990), Pereira et al. (1988) and Viégas (1985).

The assessed variables revealed a quadratic response to varying doses of controlled-release fertilizer (ALL), as is illustrated in Figures 1, 2 and 3. Maximum values of total dry matter, shoot dry matter and root dry matter were obtained using $6.4 \mathrm{~g}, 6.6 \mathrm{~g}$, and $5.9 \mathrm{~g}$ doses respectively (Figure 3), while maximum values of plant height and stem diameter were obtained with $6.3 \mathrm{~g}$ and $6.2 \mathrm{~g}$ doses respectively (Figures 1 and 2).

The optimal doses found in this study are close to the $6 \mathrm{~g} / \mathrm{L}$ dose found for seedlings of other species, including seedlings of Cerrado fruits mangaba (PEREIRA et al., 2003a,b, 2006)), araticum and cagaita (PEREIRA; PEREIRA, 2007). Using the same Osmocote $\AA$ formulation as in this study, yet with coffee seedlings, Barbizan et al. (2002) obtained maximum shoot development using $7.7 \mathrm{~g} / \mathrm{L}$ to $9.1 \mathrm{~g} / \mathrm{L}$ doses, and maximum root development using a $6.8 \mathrm{~g} / \mathrm{L}$ dose. In a study with seedlings of mimosa-like angico-branco cultivated for 95 days, Brondani et al. (2008) found higher values of number of leaves, stem diameter and seedling dry matter using a $2 \mathrm{~g} / \mathrm{L}$ dose, and a higher value of plant height using a $2.74 \mathrm{~g} / \mathrm{L}$ dose of Osmocote ${ }^{\circledR}$ (1414-14 of $\mathrm{N}-\mathrm{P}_{2} \mathrm{O}_{5}-\mathrm{K}_{2} \mathrm{O}$ ). This difference, however, may be due to differing species requirements and fertilizer sources.

The maximum values obtained in this work for different variables are compatible and, overall, higher than values found by other authors for ground-produced rubber tree seedlings (PEREIRA et al., 1988; VIÉGAS, 1985) and container-produced seedlings (COELHO, 1991; MARQUES, 1990; PEREIRA, 1983; REIS, 1989, 1991; VIÉGAS et al., 1992) using other fertilizer sources (traditional). The superior plant development found in this study, in comparison with results found by Reis (1989, 1991), is due to the larger volume of containers and, as a result, the increased availability of substrate, water and fertilizer, as well as the longer trial period.

Table 1 - Analysis of variance summary for plant height (ALT), stem diameter $5 \mathrm{~cm}$ above root collar (DC), total dry matter (MST), shoot dry matter (MSPA) and root dry matter (MSR) of rubber tree rootstocks at age eight months, subjected to varying doses of controlled-release fertilizer (ALL).

Tabela 1 - Resumo das análises de variância para altura da planta (ALT), diâmetro do caule a 5 cm do coleto (DC), matéria seca total (MST), da parte aérea (MSPA) e das raízes (MSR) de porta-enxertos de seringueira aos oito meses de idade, submetidos a doses de adubo de liberação lenta (ALL).

\begin{tabular}{|c|c|c|c|c|c|c|}
\hline \multirow{2}{*}{ Source of variation } & \multirow{2}{*}{ Degree of freedom } & \multicolumn{5}{|c|}{ Mean Square Residual and Significance Levels } \\
\hline & & $\operatorname{ALT}(\mathrm{cm})$ & $\mathrm{DC}(\mathrm{mm})$ & $\operatorname{MST}(\mathrm{g})$ & $\operatorname{MSPA}(\mathrm{g})$ & $\operatorname{MSR}(\mathrm{g})$ \\
\hline Fertilizer dose & 3 & $1516.70 * *$ & $58.71 * *$ & $19167.29 * *$ & $8999.17 * *$ & $2101.28^{* *}$ \\
\hline Block & 7 & $4.85^{\mathrm{ns}}$ & $0.20^{\mathrm{ns}}$ & $140.37 * *$ & $78.52 * *$ & $10.75^{\mathrm{ns}}$ \\
\hline Residual & 21 & 4.91 & 0.16 & 20.61 & 12.74 & 7.64 \\
\hline Total & 31 & & & & & \\
\hline $\begin{array}{l}\text { Coefficient of } \\
\text { variation }(\%)\end{array}$ & & 3.15 & 4.09 & 4.90 & 6.02 & 8.30 \\
\hline
\end{tabular}

ns are nonsignificant values, ${ }^{*} \mathrm{e}^{*}$ are significant values by the F-test at the $5 \%$ and $1 \%$ probability levels.

Cerne, Lavras, v. 18, n. 2, p. 239-245, abr./jun. 2012 


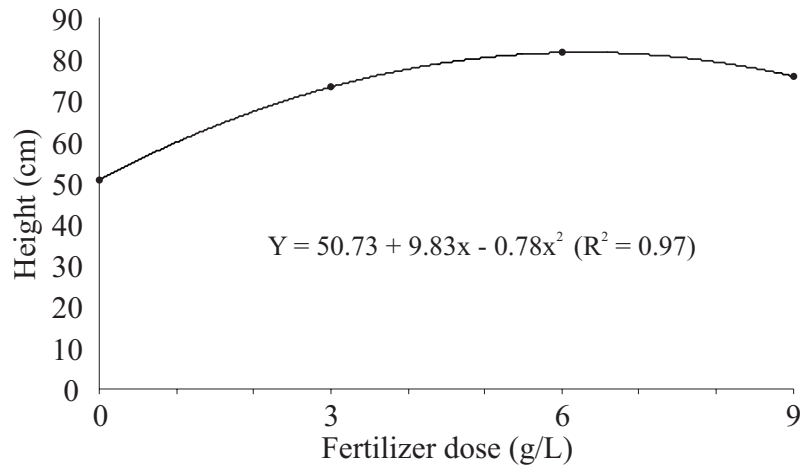

Figure 1 - Height of rubber tree rootstocks at age eight months, subjected to doses of controlled-release fertilizer (ALL).

Figura 1 - Altura de porta-enxertos de seringueira aos oito meses de idade, submetidos a doses de adubo de liberação lenta (ALL).

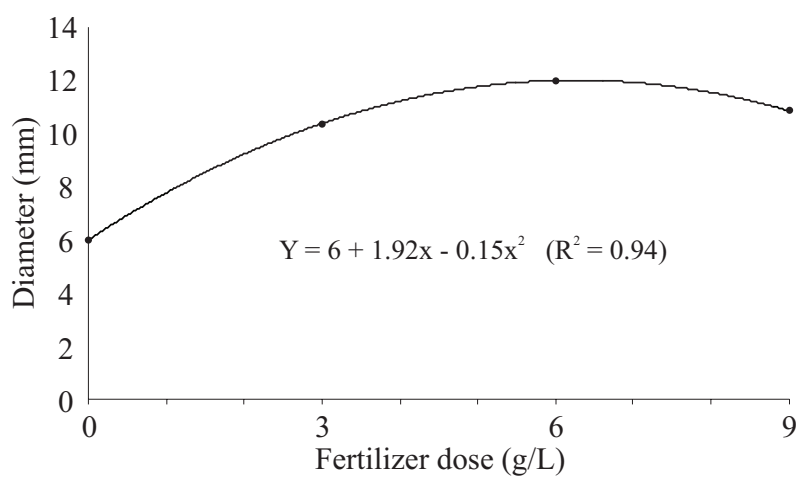

Figure 2 - Stem diameter $5 \mathrm{~cm}$ above root collar of rubber tree rootstocks at age eight months, subjected to doses of controlledrelease fertilizer (ALL).

Figura 2-Diâmetro do caule a $5 \mathrm{~cm}$ do coleto de porta-enxertos de seringueira aos oito meses de idade, submetidos a doses de adubo de liberação lenta (ALL).

Absence of fertilizer affected the development of rootstocks as plants failed to reach the minimum stem diameter at age eight months $(1 \mathrm{~cm})$ stipulated by Normative Standard no. 29 from the Ministry of Agriculture, Livestock and Supply (BRASIL, 2009), the department that sets standards for production and commercialization of rubber tree seedlings (Table 2).

The doses $3 \mathrm{~g}, 6 \mathrm{~g}$ and $9 \mathrm{~g}$ of controlled-release fertilizer per liter of substrate differed from each other as to the resulting plant development, yet they enabled producing rootstocks with larger stem diameter than the minimum standard as well as a high percentage of plants suitable for green grafting, close to $100 \%$ (Table 2).

Cerne, Lavras, v. 18, n. 2, p. 239-245, abr./jun. 2012

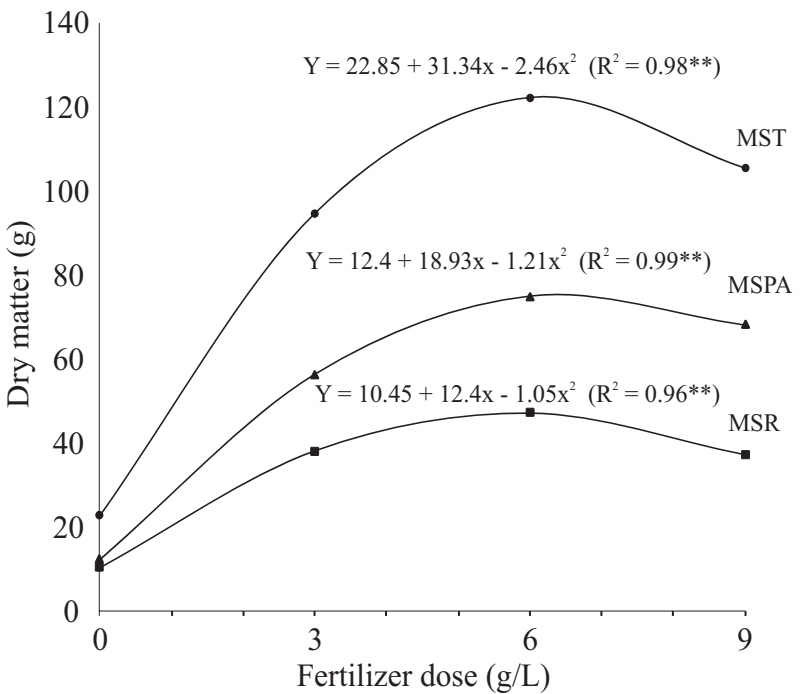

Figure 3 - Total dry matter (MST), shoot dry matter (MSPA) and root dry matter (MSR) of rubber tree rootstocks at age eight months, subjected to doses of controlled-release fertilizer (ALL).

Figura 3 - Matéria seca total (MST), da parte aérea (MSPA) e das raizes (MSR) de porta-enxertos de seringueira aos oito meses de idade, submetidos a doses de adubo de liberação lenta $(A L L)$.

Table 2 - Percentage of rubber tree plants suitable for green grafting at age eight months, subjected to doses of controlledrelease fertilizer (ALL).

Tabela 2 - Porcentagem de plantas de seringueira aptas a enxertia verde aos oito meses de idade, submetidas a doses de adubo de liberação lenta (ALL).

\begin{tabular}{cc}
\hline $\begin{array}{c}\text { Controlled fertilizer dose } \\
(\mathrm{g} / \mathrm{L})\end{array}$ & $\begin{array}{c}\text { Percentage of suitable } \\
\text { plants }(\%)\end{array}$ \\
\hline 0 & 0 \\
3 & 98.75 \\
6 & 99.38 \\
9 & 98.13 \\
\hline
\end{tabular}

Regardless of the fertilizer dose used, all plants sampled in the plot had a normal root system, with no twisted primary and secondary roots yet rich in tertiary and quaternary roots which helped obtain an aggregate, consolidated root block, with good prospects of successful planting.

With increasing doses of controlled-release fertilizer in the substrate, increased levels of $\mathrm{N}, \mathrm{P}, \mathrm{K}, \mathrm{Mg}$, $\mathrm{S}, \mathrm{Zn}, \mathrm{Mn}$ and Fe were found in leaves (Table 3). 
Table 3 - Nutrient levels in leaflets of rubber tree rootstocks at age eight months, subjected to doses of controlled-release fertilizer (ALL).

Tabela 3 - Teores de nutrientes em foliolos de porta-enxertos de seringueira aos oito meses de idade, submetidos a doses de adubo de liberação lenta (ALL).

\begin{tabular}{cccc}
\hline \multirow{2}{*}{ Macronutrient $(\mathrm{g} / \mathrm{kg})$} & \multicolumn{3}{c}{ Controlled fertilizer dose $(\mathrm{g} / \mathrm{L})^{*}$} \\
\cline { 2 - 4 } & 3 & 6 & 9 \\
\hline $\mathrm{N}$ & 22.3 & 29.5 & 34.7 \\
$\mathrm{P}$ & 0.9 & 1.8 & 2.5 \\
$\mathrm{~K}$ & 8.0 & 10.2 & 12.5 \\
$\mathrm{Ca}$ & 10.0 & 10.0 & 10.0 \\
$\mathrm{Mg}$ & 2.0 & 2.0 & 2.4 \\
$\mathrm{~S}$ & 1.8 & 1.9 & 2.3 \\
\hline Micronutrient $(\mathrm{mg} / \mathrm{kg})$ & & & \\
\hline $\mathrm{B}$ & 93.8 & 93.7 & 93.8 \\
$\mathrm{Cu}$ & 23.8 & 26.7 & 25.5 \\
$\mathrm{Fe}$ & 154.9 & 157.2 & 177.2 \\
$\mathrm{Mn}$ & 155.3 & 187.0 & 215.0 \\
$\mathrm{Zn}$ & 23.1 & 26.0 & 32.5 \\
\hline
\end{tabular}

*Unfertilized plants were deprived of leaves and thus not evaluated.

The $3 \mathrm{~g} / \mathrm{L}$ dose was found to limit plant development as it failed to suffice nutritionally, affecting plant quality and providing below-standard levels of $\mathrm{N}, \mathrm{P}$ and $\mathrm{K}$ in comparison to reference values cited by Pereira and Pereira (1986), Raij and Cantarella (1997) and Shorrocks (1979). As a result, grafting procedures on deficient plants will also affect their development since growth is directly related to nutrient reserve in rootstocks.

The $6 \mathrm{~g} / \mathrm{L}$ dose was found to promote fuller rootstock development and more suitable nutrition, providing adequate leaf nutrient levels according to the above authors. The $9 \mathrm{~g} / \mathrm{L}$ dose, on the other hand, was found to be excessive, providing higher leaf nutrient levels (N, P, K, Mg, Zn, Mn and $\mathrm{Fe}$ ) and yet poorer plant development.

The results of rootstock development obtained in this study indicate the feasibility of producing rubber tree seedlings in hanging containers with a capacity of two liters of substrate composed of pine bark, peat and vermiculite and using controlled-release fertilizer over 8 to 9 months, at a dose of $6 \mathrm{~g} / \mathrm{L}$, as suggested by Pereira et al. (2007).

\section{CONCLUSIONS}

Under the conditions of this work, it was concluded that nutrition procedures of rubber tree rootstocks can be done over 8 to 9 months using controlled-release fertilizer composed of $\mathrm{N}(15 \%), \mathrm{P}_{2} \mathrm{O}_{5}(9 \%), \mathrm{K}_{2} \mathrm{O}(12 \%), \mathrm{Mg}(1 \%)$, $\mathrm{S}(2.3 \%), \mathrm{B}(0.02 \%), \mathrm{Cu}(0.05 \%), \mathrm{Fe}(1 \%), \mathrm{Mn}(0.06 \%)$, Mo (0.02\%) and $\mathrm{Zn}(0.05 \%)$.

The $6 \mathrm{~g} / \mathrm{L}$ dose was found to promote fuller plant development as to height, stem diameter, total dry matter, shoot dry matter and root dry matter, as well as better nutrition.

The $0 \mathrm{~g} / \mathrm{L}, 3 \mathrm{~g} / \mathrm{L}$ and $9 \mathrm{~g} / \mathrm{L}$ doses were found to be unsuitable for rootstock nutrition.

\section{REFERENCES}

BARBIZAN, E. L.; LANA, R. M. Q.; MENDONÇA, F. C.; MELO, B. de; SANTOS, C. M. dos; MENDES, A. F. Produção de mudas de cafeeiro em tubetes associada a diferentes formas de aplicação de fertilizantes. Ciência e Agrotecnologia, Lavras, v. 26, n. 6, p. 1471-1480, dez. 2002. Edição especial.

BRASIL. Ministério da Agricultura, Pecuária e Abastecimento. Instrução Normativa $n^{\circ} 29$, de 5 de agosto de 2009. Aprova as normas para a produção de sementes e de mudas de seringueira (Hevea spp.). Diário Oficial [da] República Federativa do Brasil, Brasília, 6 ago. 2009. Seção 1, p. 5.

BRONDANI, G. E.; SILVA, A. J. C.; REGO, S. S.; GRISI, F. A.; NOGUEIRA, A. C.; WENDLING, I.; ARAUJO, M. A. de. Fertilização de liberação controlada no crescimento inicial de angico-branco. Scientia Agraria, Curitiba, v. 9, n. 2, p. 167176, 2008.

CAMARGO, A. P. de; MARIN, F. R.; CAMARGO, M. B. P. de. Zoneamento climático da heveicultura no Brasil. Campinas: Embrapa Monitoramento por Satélite, 2003. 19 p. (Documentos, 24).

COELHO, L. C. Necessidade de calagem, adubação potássica e relações cálcio, magnésio e potássio para produção de porta-enxertos de seringueira. 1991. 55 p. Dissertação (Mestrado em Produção Vegetal) - Universidade Federal de Viçosa, Viçosa, 1991.

CORTEZ, J. V. Reflexões sobre as projeções do consumo de borracha natural no Brasil até o ano 2030. São Paulo: Associação Paulista de Produtores e Beneficiadores de Borracha, 2005. Disponível em: <http://www.apabor.org.br / artigos>. Acesso em: 15 nov. 2009.

Cerne, Lavras, v. 18, n. 2, p. 239-245, abr./jun. 2012 
GAMEIRO, A. H. Perspectivas para o mercado e viabilidade da produção de borracha natural. In: WORKSHOP SERINGUEIRA EM TABAPUÃ, 2009, Tabapuã. Anais... Tabapuã: Apabor, 2009. Disponível em: <http://www.apabor. org.br/workshop/091017/index.php>. Acesso: 7 dez. 2009.

MARQUES, R. Efeitos do fósforo e zinco na nutrição e crescimento de porta-enxertos de seringueira (Hevea brasiliensis Müell. Arg.). 1990. 110 p. Dissertação (Mestrado em Solos e Nutrição de Plantas) - Escola Superior de Agricultura de Lavras, Lavras, 1990.

PEREIRA, A. V. Efeito de tipos e tamanhos de sacos plásticos, sobre o desenvolvimento de porta-enxertos de seringueira (Hevea sp.). 1983. 44 f. Dissertação (Mestrado em Fitotecnia) - Escola Superior de Agricultura de Lavras, Lavras, 1983.

PEREIRA, A. V.; PEREIRA, E. B. C. Adubação de seringais de cultivo na Amazônia: primeira aproximação. Manaus: Embrapa/CNPSD, 1986. 32 p. (Circular técnica, 8).

PEREIRA, A. V.; PEREIRA, E. B. C.; JUNQUEIRA, N. T. V.; FIALHO, J. F.; ALVES, R. T.; TIRABOSCHI, G. M. N. Cultura da seringueira no cerrado. Planaltina: Embrapa Cerrados, 2001. 59 p.

PEREIRA, A. V.; ZAMUNÉR FILHO, A. N.; SILVA, R. S.; ANTONINI, J. C. dos A.; VOCURCA, H.; PEREIRA, E. B. C. Produção de mudas de seringueira em viveiro suspenso. In: CONGRESSO BRASILEIRO DE HEVEICULTURA, 2007, Guarapari. Anais... Guarapari: INCAPER, 2007. CD-ROM.

PEREIRA, E. B. C.; PEREIRA, A. V. Propagação de fruteiras nativas do cerrado. In: . Prêmio CREA Goiás de

Meio Ambiente, 2006: compêndio dos trabalhos premiados. Goiânia: CREA, 2007. p. 171-191.

PEREIRA, E. B. C.; PEREIRA, A. V.; JUNUEIRA, N. T. V. Propagação por sementes. In: SILVA JÚNIOR, J. F. da; LÉDO, A. da S. (Ed.). A cultura da mangaba. Aracaju: Embrapa Tabuleiros Costeiros, 2006. p. 91-109.

PEREIRA, E. B. C.; PEREIRA, A. V.; PACHECO, A. Adubação de mudas de mangabeira em sacos plásticos com substrato de areia grossa. In: SIMPÓSIO BRASILEIRO SOBRE A CULTURA DA MANGABA, 2003, Aracajú. Anais... Aracajú: Embrapa Tabuleiros Costeiros, 2003a. CDROM.

Cerne, Lavras, v. 18, n. 2, p. 239-245, abr./jun. 2012
PEREIRA, E. B. C.; PEREIRA, A. V.; PACHECO, A. Efeito do substrato e da adubação no crescimento e na sobrevivência de mudas de mangabeira em tubetes. In: SIMPÓSIO BRASILEIRO SOBRE A CULTURA DA MANGABA, 2003, Aracajú. Anais... Aracajú: Embrapa Tabuleiros Costeiros, 2003b. CD-ROM.

PEREIRA, E. B. C.; PEREIRA, A. V.; SILVA, S. E. L. da. Níveis de N, P, K e Mg para viveiro de seringueira em Latossolo Amarelo de textura muito argilosa. Revista Brasileira de Ciência do Solo, Campinas, v. 12, p. 143-146, 1988.

PERIN, J. R.; CARVALHO, S. A.; MATTOS JÚNIOR, D.; CANTARELLA, H. Efeitos de substratos e doses de fertilizantes de liberação lenta no teor de clorofila e desenvolvimento vegetativo do limoeiro "Cravo" em tubetes. Revista Laranja, Cordeirópolis, v. 20, n. 2, p. 457-462, 1999.

RAIJ, B. van; CANTARELLA, H. Outras culturas industriais. In: RAIJ, B. van; CANTARELLA, H.; QUAGGIO, J. A.; FURLANI, A. M. C. Recomendação de adubação e calagem para o estado de São Paulo. 2. ed. Campinas: Instituto Agronômico, 1997. p. 231-244. (Boletim técnico, 100).

REIS, E. L. Processo de obtenção de mudas de seringueira em tubetes: (1) avaliação do desenvolvimento das plântulas com diferentes adubações. Agrotrópica, Ilhéus, v. 1, n. 3, p. 194-197, 1989.

REIS, E. L. Processo de obtenção de mudas de seringueira em tubetes: (2) influência de diferentes substratos e adubações. Agrotrópica, Ilhéus, v. 3, n. 2, p. 81-86, 1991.

SAMPAIO FILHO, J. de A.; PEREIRA, A. V.; VALE, A. A. Q. do; CORTEZ, J. V.; PEREIRA, J. da P.; TEGANI, W.; ROSSMANN, H. Câmara setorial da cadeia produtiva da borracha natural. In: VILELA, D.; ARAÚJO, P. M. M. Contribuições das câmaras setoriais e temáticas à formulação de políticas públicas e privadas para o agronegócio. Brasília: MAPA/SE/CGAC, 2006. p. 330-353.

SCOTTS UK PGB. Osmocote ${ }^{\circledR}$ 14-14-14: working principle. London, 2002. Disponível em: $<$ http://www.btinternet. com/ mark.milburn/141414.htm>. Acesso em: 29 nov. 2008.

SHORROCKS, V. M. Deficiências nutricionais em Hevea e plantas de cobertura associadas. Brasília: Sudhevea, 1979. $76 \mathrm{p}$. 
VIÉGAS, I. de J. M. Doses de NPK em viveiro de Hevea spp. na obtenção de plantas aptas para enxertia em Latossolo Amarelo textura média, na Ilha do Mosqueiro-PA. 1985. 71 f. Dissertação (Mestrado em Agronomia) - Escola Superior de Agricultura “Luiz de Queiroz”, Piracicaba, 1985.
VIÉGAS, I. de J. M.; HAAG, H. P.; BUENO, N.; PEREIRA, J. da P. Nutrição mineral de seringueira: XII., absorção de macronutrientes e micronutrientes nos primeiros 240 dias. Sciencia Agricola, Piracicaba, v. 49, n. 1, p. 41-52, 1992.

Cerne, Lavras, v. 18, n. 2, p. 239-245, abr./jun. 2012 